\title{
Age-Related Susceptibility to Chlordecone-Potentiated Carbon Tetrachloride Hepatotoxicity and Lethality Is Due to Hepatic Quiescence
}

\author{
ABRAHAM DALU, ALAN WARBRITTON, THOMAS J. BUCCI, AND \\ HARIHARA M. MEHENDALE \\ Division of Pharmacology and Toxicology, College of Pharmacy and Health Sciences, Northeast \\ Louisiana University, Monroe, Louisiana 71209-0470 [A.D., H.M.M.] and Pathology Associates, Inc., \\ National Center for Toxicological Research, Jefferson, Arkansas 72079 [A.W., T.J.B.]
}

\begin{abstract}
Previous studies revealed that postnatally developing rats are resilient to the lethal effects of chlordecone (CD) + carbon tetrachloride $\left(\mathrm{CCl}_{4}\right)$ combination. The objective of this study was to investigate the underlying mechanism. We hypothesized that ongoing cell division and cell cycle progression as well as additional toxicant-induced stimulation of tissue repair help in restraining the progression of injury on the one hand, and in recovery through speedy healing on the other. Postnatally developing (20- and 45-d) and adult (60-d) male Sprague-Dawley rats were challenged with a nontoxic single dose of $\mathrm{CCl}_{4}(100 \mu \mathrm{L} / \mathrm{kg}$, i.p.) or corn oil after pretreatment with either dietary $\mathrm{CD}(10$ $\mathrm{ppm}$ ) or normal dict (ND) for $15 \mathrm{~d}$. Hepatocellular injury was assessed by measuring serum enzymes [alanine transaminase (ALT), sorbitol dehydrogenase (SDH)], and bilirubin, as well as by histopathologic examination of liver sections during a time course of $0-96 \mathrm{~h}$ after the administration of $\mathrm{CCl}_{4}$ or corn oil. Hepatocellular regeneration was assessed by $\left[{ }^{3} \mathrm{H}\right]$ thymidine $\left(\left[{ }^{3} \mathrm{H}\right] \mathrm{T}\right)$ incorporation into hepatic nuclear DNA. In $\mathrm{CD}+\mathrm{CCl}_{4}$ treatment, ALT, SDH, and bilirubin levels peaked between 36 and $48 \mathrm{~h}$ after $\mathrm{CCl}_{4}$. All 20-d-old rats survived the challenge of $\mathrm{CD}+\mathrm{CCl}_{4}$. CD-potentiated hepatotoxicity and lethality of $\mathrm{CCl}_{4}$ begin to be manifested in 45 -d-old rats at $48 \mathrm{~h}$ and later times ( $25 \%$ mortality), whereas adult rats experience progressive hep-
\end{abstract}

ABSTRACT
A greater understanding of the mechanisms underlying the influence of age on the susceptibility to chemical injury is critical in dealing with hepatotoxicity in newborn, young, adult, and elderly patients. Early studies showed that chemicalinduced hepatic injury and disease can either increase or decrease with age (1). Recent studies have demonstrated that neonates and young rats are resilient to a number of hepato-

Received October 10, 1994; accepted April 28, 1995.

Correspondence and reprint requests: Dr. Harihara M. Mehendale, Division of Pharmacology and Toxicology, College of Pharmacy and Health Sciences, Northeast Louisiana University, Monroc, LA 712019-0470. atotoxic injury and $100 \%$ mortality by $72 \mathrm{~h}$. In contrast, regardless of pretreatment, 20-d-old rats recover fully from injury by 72 $\mathrm{h}$ after $\mathrm{CCl}_{4}$ treatment. The rapid recovery of 20 -d-old rats was associated with a combination of higher level of ongoing cell division and additional sustained stimulation of $\left[{ }^{3} \mathrm{H}\right] \mathrm{T}$ incorporation from 24 to $72 \mathrm{~h}$ after the administration of $\mathrm{CCl}_{4}$. In the older rats (45- or 60-d-old) this response was significantly delayed and attenuated. Ongoing cell division and $\mathrm{CCl}_{4}$-stimulated regeneration were inversely related to postnatal development (20-, 45-, or 60-d). These biochemical, histopathological, and $\left[{ }^{3} \mathrm{H}\right] \mathrm{T}$ incorporation studies suggest that the liver of younger rats has greater plasticity for repair after toxic injury whereas adult liver is much more quiescent in this regard. (Pediatr Res 38: 140-148, 1995)
CD, chlordecone
TGF, transforming growth factor
ND, normal diet
ALT, alanine transaminase
$\left[{ }^{3} \mathrm{H}\right] \mathrm{T},\left[{ }^{3} \mathrm{H}\right]$ thymidine
SDH, sorbitol dehydrogenase
AUC, area under the curves

Abbreviations

toxicants such as $\mathrm{CCl}_{4}(2-5)$, allyl alcohol (2), galactosamine (6), and acetaminophen (7). Most interestingly, young rats survive exposure to individually nontoxic combination of CD $+\mathrm{CCl}_{4}(5)$, known to cause $100 \%$ mortality in adult rats $(8,9)$. Because there is a need to understand the mechanisms underlying this age-related difference in toxicity, and because the $\mathrm{CD}$ $+\mathrm{CCl}_{4}$ model offers a unique opportunity to investigate these mechanisms, this model was used in the present studies.

$\mathrm{CCl}_{4}$ is bioactivated by cytochrome $\mathrm{P} 450$ to $\mathrm{CCl}_{3}$ free radical, which is further converted to a peroxy radical, $\mathrm{CCl}_{3} \mathrm{O}_{2}$ (10). These free radicals readily react with polyunsaturated fatty acids of the endoplasmic reticulum and other hepatocel- 
lular membranes to initiate the formation of organic lipid peroxides. In the presence of cellular $\mathrm{O}_{2}$, these organic peroxy radicals in turn can react with other polyunsaturated fatty acids to perpetuate a series of self-propagating chain reactions. Substantial experimental data suggest that stimulation of hepatocellular regeneration and tissue repair mechanisms plays a critical role in the recovery from the limited toxic injury inflicted by a low dose of $\mathrm{CCl}_{4}(11,12)$. Rats receiving a low dose of $\mathrm{CCl}_{4}(100 \mu \mathrm{L} / \mathrm{kg})$ alone exhibit very limited liver injury as evidenced by histopathologic observations at $6 \mathrm{~h}$ after the administration of $\mathrm{CCl}_{4}$. This injury is progressive up to 12 $\mathrm{h}$, followed by recovery by $24 \mathrm{~h}(11,13)$. Prior exposure to a nontoxic dose of CD (10 ppm in diet for $15 \mathrm{~d})$ is known to amplify hepatotoxicity and lethality of $\mathrm{CCl}_{4}$ in male (8) and female (9) adult rats. Studies have revealed that the $\mathrm{CD}+\mathrm{CCl}_{4}$ combination inhibits $\mathrm{CCl}_{4}$-induced liver cell division and tissue repair, thereby permitting unrestrained progression of injury leading to hepatic failure and death $(8,9,13-17)$.

Newborn and young animals are commonly assumed to be more sensitive to many drugs and chemicals $(18,19)$. However, experimental data suggest that newborns are less sensitive to a number of chemicals such as $\mathrm{CCl}_{4}$ whose toxicity depends upon metabolic activation to toxic species (20). In these studies, lower cytochrome P450 levels is offered as a mechanism for resiliency of newborns to toxicity of $\mathrm{CCl}_{4}$. In contrast to the above studies, Cai and Mehendale (5) reported that postnatally developing rats exhibit resiliency not only to $\mathrm{CCl}_{4}$ alone, but also to the deadly combination of $\mathrm{CD}+\mathrm{CCl}_{4}$. These studies have also shown that this resiliency is not related to differences in cytochrome $\mathrm{P} 450$ levels or bioactivationdependent mechanisms but is more likely due to greater plasticity in liver cell division and tissue repair mechanisms in younger animals, in contrast to the quiescent nature of adult liver.

The objective of this study was to investigate the mechanisms underlying the resiliency of rats to $\mathrm{CCl}_{4}$ or to $\mathrm{CD}+$ $\mathrm{CCl}_{4}$ hepatotoxicity and lethality during early postnatal development. To this end, the temporal aspects of the magnitude of injury inflicted by $\mathrm{CCl}_{4}$ and the role of ongoing as well as stimulated tissue repair during the course of injury and recovery was investigated. We report here that the remarkable plasticity of growing livers during early postnatal development enables the rats to restrain toxic injury and restore liver function, leading to recovery from injury.

\section{METHODS}

Chemicals. Unless otherwise stated, all chemicals and enzyme kits used in this study were purchased from Sigma Chemical Co. (St. Louis, MO). $\left[{ }^{3} \mathrm{H}\right] \mathrm{T}$ (sp act, $2 \mathrm{Ci} / \mathrm{mmol}$ ) was purchased from Moravek Biochemicals (Brea, CA).

Animals. Postnatally developing (20 and $45 \mathrm{~d}$ ) and adult (60 d) male Sprague-Dawley rats were bred and maintained in our Central Animal Facilities (for the entire experiment) under controlled conditions of temperature $\left(20 \pm 1^{\circ} \mathrm{C}\right)$, relative humidity (50-80\%), and illumination ( $12 \mathrm{~h}$ light, $12 \mathrm{~h}$ dark). All rats had free access to commercial powdered food (Teklad
$4 \%$ crude fat rat/mouse diet no. 7001 , Indianapolis, IN) and water.

Treatment. Rats (30 and $45 \mathrm{~d}$ ) were maintained on the standard rodent powdered diet with or without $10 \mathrm{ppm} \mathrm{CD}$ for $15 \mathrm{~d}$ as described by Curtis and Mehendale (14). Newly parturent female rats were maintained on a similarly prepared diet (30 ppm CD) or ND for $15 \mathrm{~d}$, starting from $5 \mathrm{~d}$ postparturition such that their 20 -d-old offspring would have been exposed to $\mathrm{CD}$ for $15 \mathrm{~d}$ through milk feeding (5). This protocol has been previously validated to be equivalent to $10 \mathrm{ppm} \mathrm{CD}$ dietary exposure (5). On d 16, rats from each dietary protocol were challenged with single injection of $\mathrm{CCl}_{4}(100 \mu \mathrm{L} / \mathrm{kg}, \mathrm{i} . \mathrm{p}$. $)$ in corn oil $(1: 1)$ or corn oil alone. Blood and liver samples were collected at $0,6,12,24,36,48,72$, and $96 \mathrm{~h}$ after $\mathrm{CCl}_{4}$ or corn oil treatment. The blood samples were used to determine serum enzymes (ALT and SDH) and serum total bilirubin. Liver samples were used to determine $\left[{ }^{3} \mathrm{H}\right] \mathrm{T}$ incorporation into hepatic nuclear DNA, and for histopathologic examination.

$\mathrm{CCl}_{4}$ induced lethality. Any lethality induced by a single dose of $\mathrm{CCl}_{4}(100 \mu \mathrm{L} / \mathrm{kg}$, i.p., was assessed in 20-, 45-, and 60 -d-old rats maintained on ND or CD diet for $15 \mathrm{~d}$. The rats were observed twice daily for $14 \mathrm{~d}$, and mortality was recorded. Results are reported for up to $72 \mathrm{~h}$, because all rats surviving at $72 \mathrm{~h}$ survived thereafter.

Serum enzymes and bilirubin. ALT (EC 2.6.1.2) and SDH (EC 1.1.1.1.4) were measured as markers of liver injury by the methods of Bergmeyer et al. (21) and Asada and Galambos (22), respectively. Total bilirubin was measured as a marker of liver function as described by Michaelsson (23).

In vivo incorporation of $\left.{ }^{3} \mathrm{H}\right] \mathrm{T}$ into hepatocellular nuclear DNA. $\left[{ }^{3} \mathrm{H}\right] \mathrm{T}$ was administered at a dose of $50 \mu \mathrm{Ci} / 300$ of $\mathrm{g}$ body weight (i.p.) $2 \mathrm{~h}$ before sacrifice. The procedure used for isolation of liver nuclear DNA was that described by Chang and Looney (24). DNA content of the supernatant fraction was measured with the diphenylamine reaction as described by Burton (25). $\left[{ }^{3} \mathrm{H}\right] \mathrm{T}$ incorporation data were expressed as $\mathrm{cpm} / \mathrm{mg}$ DNA.

Hepatopathology. Immediately after the surgical removal of the liver, sections of the liver were washed in normal saline $(0.9 \%)$ and fixed in phosphate buffered $10 \%$ formaldehyde, embedded in paraffin, and sectioned ( $5 \mu \mathrm{m}$ thick). The sections were stained with hematoxylin and eosin for histopathologic examination under a light microscope.

Statistical analysis. The data are presented as the mean \pm SEM. A completely randomized design and a general linear model of regression analysis from a statistical analysis system were used to conduct a multiple linear regression. Significant differences were calculated using Duncan's new multiple range comparisons. The criterion for significance was set at $p \leq 0.05$. The AUC for injury or tissue repair were calculated using a BASIC statistical program.

\section{RESULTS}

Lethality. The mortality induced by a single nontoxic dose of $\mathrm{CCl}_{4}(100 \mu \mathrm{L} / \mathrm{kg}$, i.p. $)$ in $20-, 45-$, and 60 -d-old rats maintained on either ND or $10 \mathrm{ppm}$ CD diet was observed and recorded for $14 \mathrm{~d}$. Mortality did not occur in rats given ND + 
$\mathrm{CCl}_{4}$ combination. In CD-pretreated rats, 25 and $100 \%$ mortality occurred in 45- and 60-d-old rats, respectively, within 72 $h$ after the administration of $\mathrm{CCl}_{4}$. In contrast, mortality did not occur in 20-d-old rats regardless of pretreatment.

Hepatotoxicity of $\mathrm{CCl}_{4}$. Hepatotoxicity was assessed by measuring serum ALT, SDH, and total bilirubin levels during a time course after the injection of $\mathrm{CCl}_{4}$. It is evident from the ALT, SDH, and bilirubin data (Figs. 1-3) that regardless of age, $\mathrm{CCl}_{4}$ treatment resulted in marginal elevation of ALT, $\mathrm{SDH}$, and bilirubin levels in rats maintained on ND. Rats of all age groups promptly recovered from this injury. In contrast, hepatotoxicity was dramatically amplified in rats maintained on the $\mathrm{CD}$ diet. Significant elevations of serum enzymes and bilirubin were observed as early as $6 \mathrm{~h}$, the peak occurring between 36 and $48 \mathrm{~h}$ in all age groups after $\mathrm{CCl}_{4}$ (Figs. 1-3).

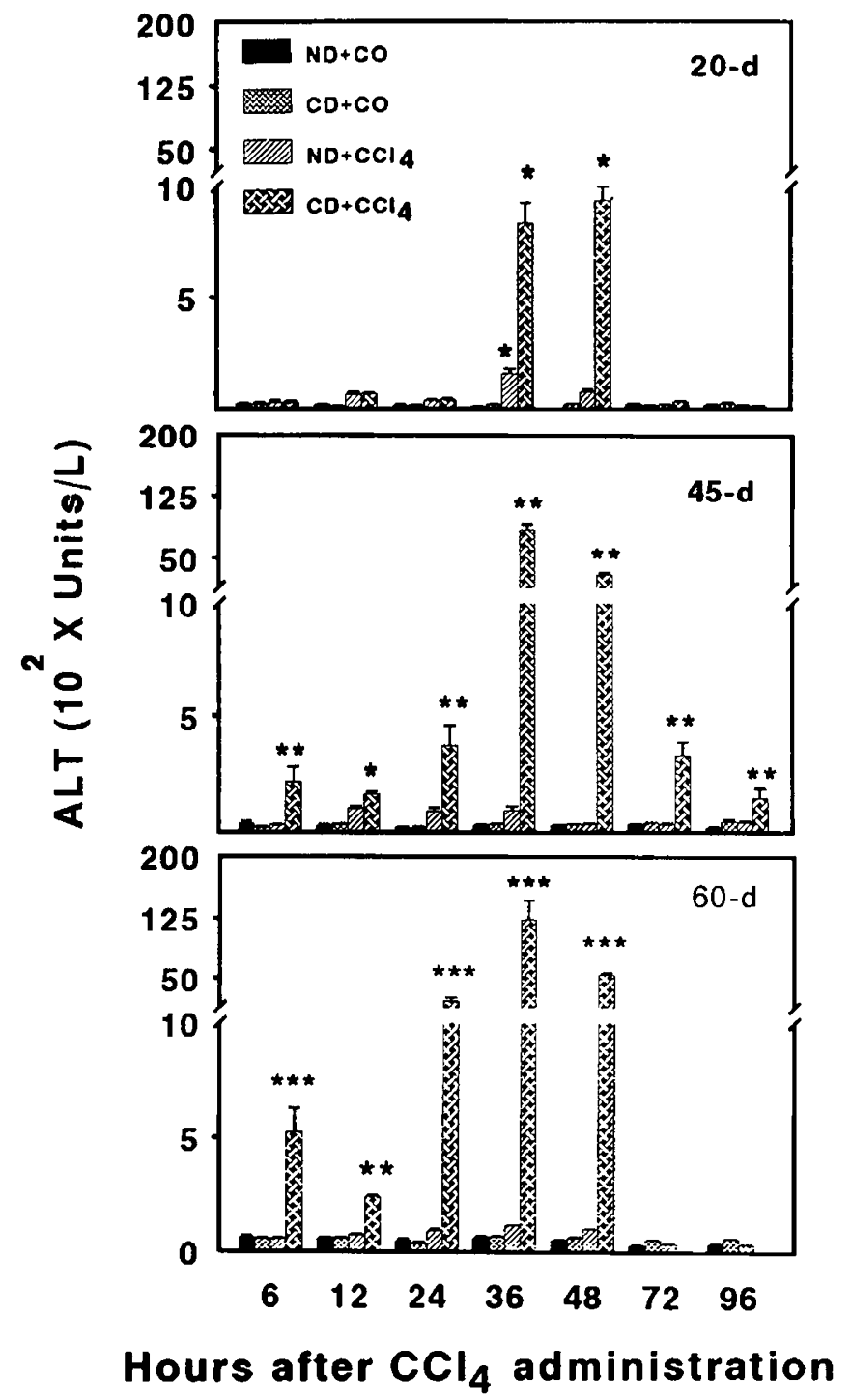

Figure 1. Serum ALT activity during a time course of $96 \mathrm{~h}$ after $\mathrm{CCl}_{4}(100$ $\mu \mathrm{L} / \mathrm{kg}$, i.p.) administration to $20-, 45-$, and 60 -d-old rats maintained on either $\mathrm{ND}$ or $10 \mathrm{ppm} \mathrm{CD}$ diet for $15 \mathrm{~d}$. Values are means $\pm \mathrm{SEM}$ of four rats. * Significant increase in ALT level compared with the control of same time point; ${ }^{*}=$ significantly higher ALT level than in 20 -d-old $\mathrm{CD}+\mathrm{CCl}_{4}$ rats; *** = significantly higher ALT level compared with that in 20 - and 45-d-old $\mathrm{CD}+\mathrm{CCl}_{4}$ rats.

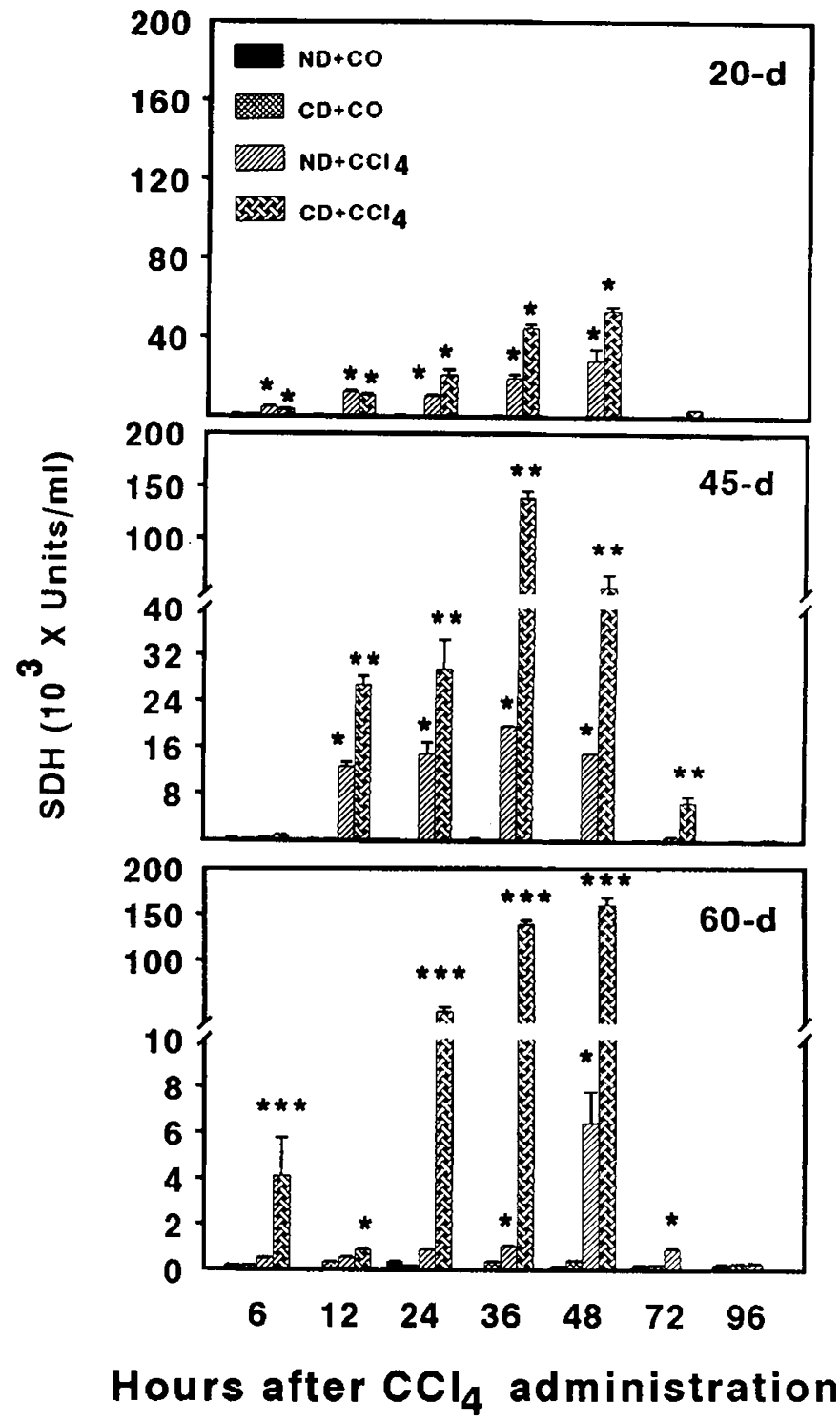

Figure 2. Serum SDH activity during a time-course of $96 \mathrm{~h}$ after $\mathrm{CCl}_{4}(100$ $\mu \mathrm{L} / \mathrm{kg}$, i.p.) administration to 20 -, 45 -, and 60 -d-old rats maintained on either ND or 10 ppm CD diet for $15 \mathrm{~d}$. Values are means \pm SEM of four rats. ${ }^{*}=$ Significant increase in SDH level compared with the control of same time point; ${ }^{*}=$ significantly higher $\mathrm{SDH}$ level than in 20 -d-old $\mathrm{CD}+\mathrm{CCl}_{4}$ rats; $* * *=$ significantly higher SDH level compared with that in 20 - and 45 -d-old $\mathrm{CD}+\mathrm{CCl}_{4}$ rats.

In 60-d-old CD-pretreated rats, the elevation of these markers of liver injury progressed with time until $100 \%$ mortality occurred by $72 \mathrm{~h}$. In 45 -d-old rats toxicity and mortality (25\%) was observed beginning at $48 \mathrm{~h}$ and later time points after $\mathrm{CCl}_{4}$. As expected, there was no mortality in 20-d-old CD + $\mathrm{CCl}_{4}$ rats. After reaching a peak, the serum enzymes fell to the background levels by $72 \mathrm{~h}$, indicating a rapid recovery of the 20-d rats from $\mathrm{CCl}_{4}$ liver injury.

Hepatopathology. Histopathologic alterations in 20-, $45-$ and $60-\mathrm{d}$-old rats were assessed by examining liver sections under a microscope for necrotic, swollen (balloon), and lipidladen hepatocytes (Figs. 4-6). Necrotic cells were identified by pyknotic nuclei and ruptured plasma membrane, whereas, swollen cells were identified by enlargement and pale staining 


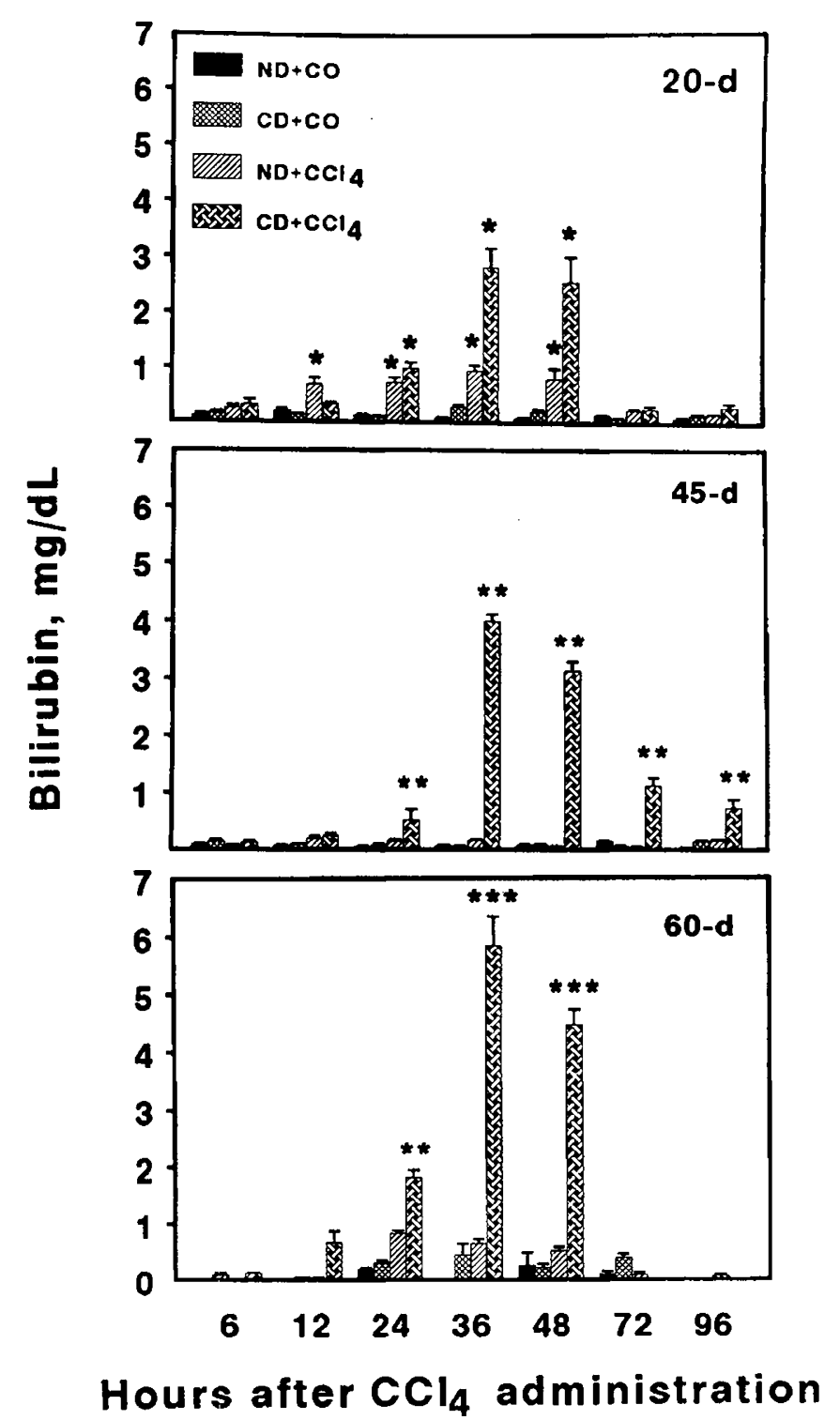

Figure 3. Serum bilirubin concentration during a time course of $96 \mathrm{~h}$ after $\mathrm{CCl}_{4}(100 \mu \mathrm{L} / \mathrm{kg}$, i.p.) administration to $20-, 45-$, and $60-\mathrm{d}$-old rats maintained on either ND or $10 \mathrm{ppm}$ CD diet for $15 \mathrm{~d}$. Values are means \pm SEM of four rats. ${ }^{*}=$ Significant increase in bilirubin level as compared with the control of same time point; ${ }^{* *}=$ significantly higher bilirubin level than in 20 -d-old $\mathrm{CD}$ $+\mathrm{CCl}_{4}$ rats; ${ }^{* * *}=$ significantly higher bilirubin level compared with that in 20- and 45-d-old $\mathrm{CD}+\mathrm{CCl}_{4}$ rats.

of the cytoplasm. Lipid-laden cells were identified by round vacuoles (droplets) within the cytoplasm. Histopathologic changes were complementary to the serum enzyme and bilirubin elevations, as well as $\left[{ }^{3} \mathrm{H}\right] \mathrm{T}$ incorporation data. Photomicrographs representing maximal liver injury inflicted by $\mathrm{CCl}_{4}$ in each age group for both ND and CD-treated rats are depicted in the middle panels of Figs. 4-6. Liver photomicrographs depicting recovery from $\mathrm{CCl}_{4}$ injury are shown in the bottom panels (Figs. 4-6). No histopathologic alterations were evident in the livers of control rats ( 0 -h time point, upper panels) regardless of dietary treatment and age. Morphologic changes were evident in 20-d-old ND- and CD-pretreated rats as early as $6 \mathrm{~h}$ after $\mathrm{CCl}_{4}$ treatment. In 20 -d-old $\mathrm{ND}$ rats, maximum injury was observed at $24 \mathrm{~h}$ after $\mathrm{CCl}_{4}$ as evidenced by the extent of necrotic, ballooned, and lipid-laden hepatocytes in the centrilobular areas (Fig. 4C). In the 20-d CD rats, the injury progressed with time, the maximum injury being evident at 48 h (Fig. 4D). Liver injury was resolved in both ND and CDpretreated rats by $72 \mathrm{~h}$ after the administration of $\mathrm{CCl}_{4}$ (Fig. 4, $E$ and $F$ ), indicating recovery from $\mathrm{CCl}_{4}$-induced liver injury by replacement of dead cells with newly divided resilient cells, thereby restoring the centrilobular architecture.

In 45- and 60-d ND rats, liver injury was evident at $6 \mathrm{~h}$ with the maximum being at $12 \mathrm{~h}$ (Figs. $5 C$ and $6 C$, respectively) after the administration of $\mathrm{CCl}_{4}$, followed by recovery at 48 (Fig. 5E) and 24 h (Fig. 6E), respectively. In 45- and 60-d-old $\mathrm{CD}$ rats, necrotic, ballooned, and lipid-laden cells were evident as early as $6 \mathrm{~h}$ after $\mathrm{CCl}_{4}$ treatment. Maximum injury was evident in both groups at $48 \mathrm{~h}$ (Figs. $5 D$ and $6 D$ ). These alterations were progressive with time until 25 and $100 \%$ mortality occurred by $72 \mathrm{~h}$ in 45 - and 60 -d-old rats, respectively. In the surviving $75 \%$ of 45 -d-old rats the morphologic alterations in the livers were minimal at $96 \mathrm{~h}$ after the administration of $\mathrm{CCl}_{4}$ (Fig. $5 F$ ), indicating resolution of the injury. The mitotic index was significantly higher in 20 - $d$ rats from 24-48 $\mathrm{h}$ after the treatment with $\mathrm{CCl}_{4}$ regardless of dietary protocol, compared with those for 45- and 60-d rats (data not presented).

In vivo incorporation of $\left.{ }^{3} H\right] T$ into hepatic nuclear DNA. $\left[{ }^{3} \mathrm{H}\right] \mathrm{T}$ incorporation was measured as an index of S-phase activity. In control rats ( 0 -h time point not treated with $\left.\mathrm{CCl}_{4}\right)$, there were no significant differences in the incorporation of $\left[{ }^{3} \mathrm{H}\right] \mathrm{T}$ among the two older age groups. Likewise, CD treatment had no significant influence on the incorporation of $\left[{ }^{3} \mathrm{H}\right] \mathrm{T}$ among the three age groups. However, the baseline values in 20 -d-old rats were significantly higher than those in older age groups (Fig. 7). Regardless of the dietary pretreatment, 20-dold rats exhibited a higher rate of $\left[{ }^{3} \mathrm{H}\right] \mathrm{T}$ incorporation than the older age groups. In both dietary groups, the wave of significantly increased $\left[{ }^{3} \mathrm{H}\right] \mathrm{T}$ incorporation began as early as $24 \mathrm{~h}$ and continued through $72 \mathrm{~h}$ after the administration of $\mathrm{CCl}_{4}$ in 20 -d-old rats. In contrast, in the older rats this response was delayed and diminished. In 45- and 60-d-old ND rats, increased $\left[{ }^{3} \mathrm{H}\right] \mathrm{T}$ incorporation occurred between 12 and $36 \mathrm{~h}$ after $\mathrm{CCl}_{4}$ treatment and then returned to the baseline, whereas $\mathrm{CD}+$ $\mathrm{CCl}_{4}$-treated rats exhibited slower and diminished $\left[{ }^{3} \mathrm{H}\right] \mathrm{T}$ incorporation, the maximum being between 48 and $72 \mathrm{~h}$ after $\mathrm{CCl}_{4}$ treatment for 45 -d-old rats and $48 \mathrm{~h}$ for 60 -d-old rats (Fig. 7). The $75 \%$ survival in 45 -d-old CD rats is presumably due to a very strong response in tissue repair activity particularly between 48 and $72 \mathrm{~h}$ after the administration of $\mathrm{CCl}_{4}$. The delayed and diminished $\left[{ }^{3} \mathrm{H}\right] \mathrm{T}$ incorporation in adult rats $(60-$ d-old) is a reflection of the suppressed S-phase stimulation and tissue repair, presumably leading to a loss of restraint on the progression of liver injury and consequently leading to $100 \%$ mortality (Fig. 6F).

\section{DISCUSSION}

Literature reports indicate that rats during early postnatal development are resilient to structurally and mechanistically 

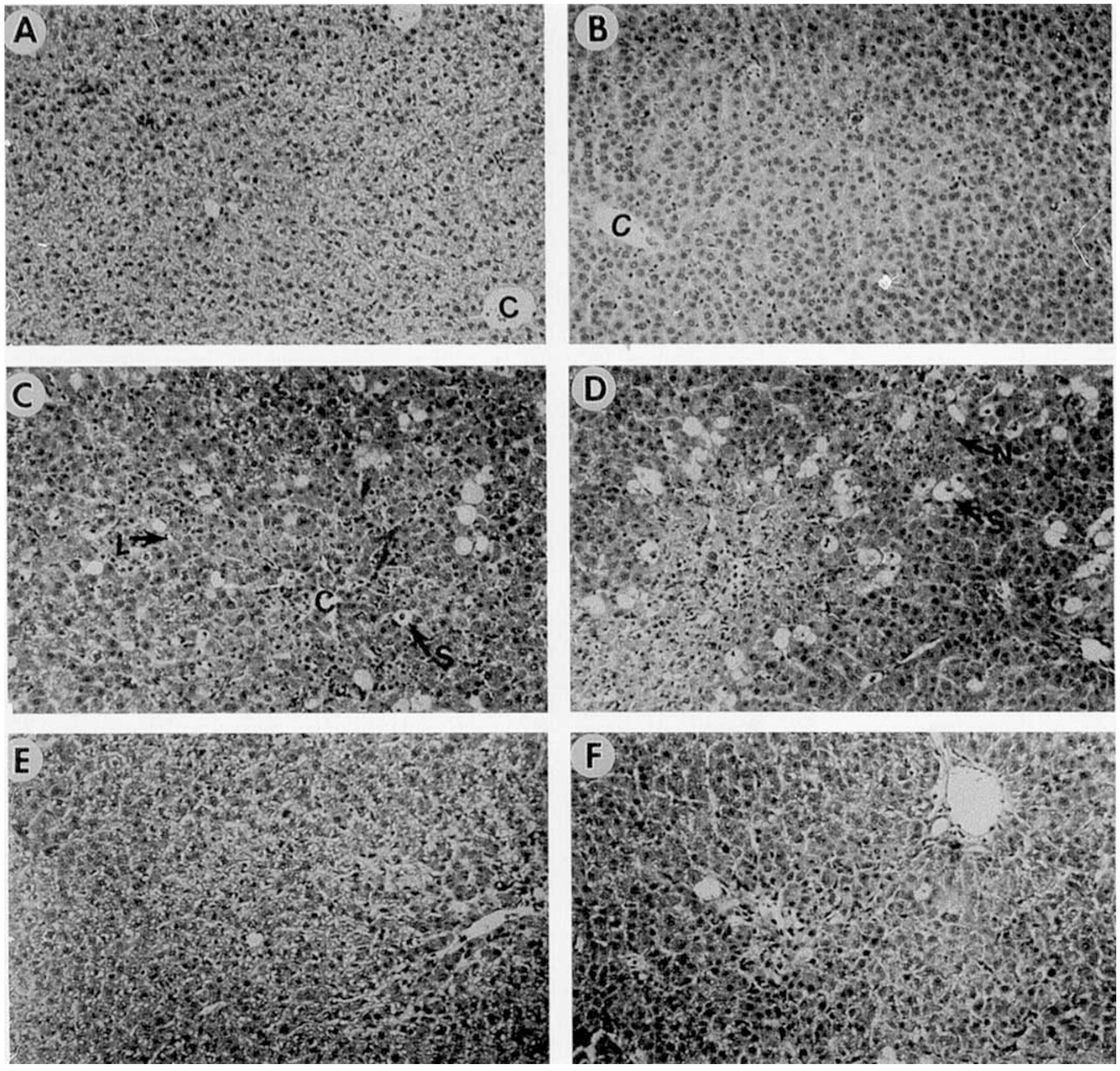

Figure 4. Photomicrographs of Iiver sections from 20-d-old rats maintained on either ND or $10 \mathrm{ppm}$ CD diet for $15 \mathrm{~d}$. On d 16 , they were challenged with a single nontoxic dose of $\mathrm{CCl}_{4}\left(100 \mu \mathrm{L} / \mathrm{kg}\right.$, i.p.). $A$, Control for $\mathrm{ND} ; B$, control for $\mathrm{CD}$ diet; $C$, time of maximum injury $(24 \mathrm{~h})$ in ND $+\mathrm{CCl}{ }_{4}$ group; $D$, time of maximum injury $(48 \mathrm{~h})$ in $\mathrm{CD}+\mathrm{CCl}_{4}$ group; $E$, time of recovery $(72 \mathrm{~h})$ in $\mathrm{ND}+\mathrm{CCl}_{4}$ group; $F$, Time of recovery $(72 \mathrm{~h})$ in $\mathrm{CD}+\mathrm{CCl}_{4}$ group. Magnification, X120. $C=$ central vein; $N=$ necrosis; $L=$ lipid; $S=$ swollen cells.

dissimilar hepatotoxicants (2-7). Early studies by Dawkins (3) and Cagen and Klaassen (4) showed that newborns are resilient to the toxic effect of $\mathrm{CCl}_{4}$. In the same studies, 4-, 7-, 10-, 14-, and 21 -d-old rats were reported to be as sensitive as adult rats. These studies used high doses of $\mathrm{CCl}_{4}(1-2 \mathrm{~mL} / \mathrm{kg})$. It is known that cell division and tissue repair mechanisms are inhibited at high doses of toxic chemicals $(26,27)$. The mechanism of resiliency in newborns to $\mathrm{CCl}_{4}$ toxicity was suggested to be due to lower amounts of cytochrome P450 required to catalyze the bioactivation of $\mathrm{CCl}_{4}(3,4)$.

In adult male rats, preexposure to $10 \mathrm{ppm} C D$ is known to result in 67 -fold amplification of $\mathrm{CCl}_{4}$ hepatotoxicity and lethality $(8,9,14)$. Cai and Mehendale (5) used a single nontoxic dose of $\mathrm{CCl}_{4}(100 \mu \mathrm{L} / \mathrm{kg}$, i.p. $)$ with or without 10 ppm CD diet to show that rat pups exhibit a remarkable resiliency to a combination of $\mathrm{CD}+\mathrm{CCl}_{4}$, which normally leads to $100 \%$ mortality in adult male (8) and female (9) rats. Further studies revealed that this is more likely related to ongoing liver growth and a promptly stimulated tissue repair mechanism rather than to differences in total cytochrome P450 levels or bioactivation-dependent mechanisms (5). In the present study, we were interested in investigating the temporal aspects of liver injury as well as tissue repair during a time course after a single low dose of $\mathrm{CCl}_{4}$ with or without prior 

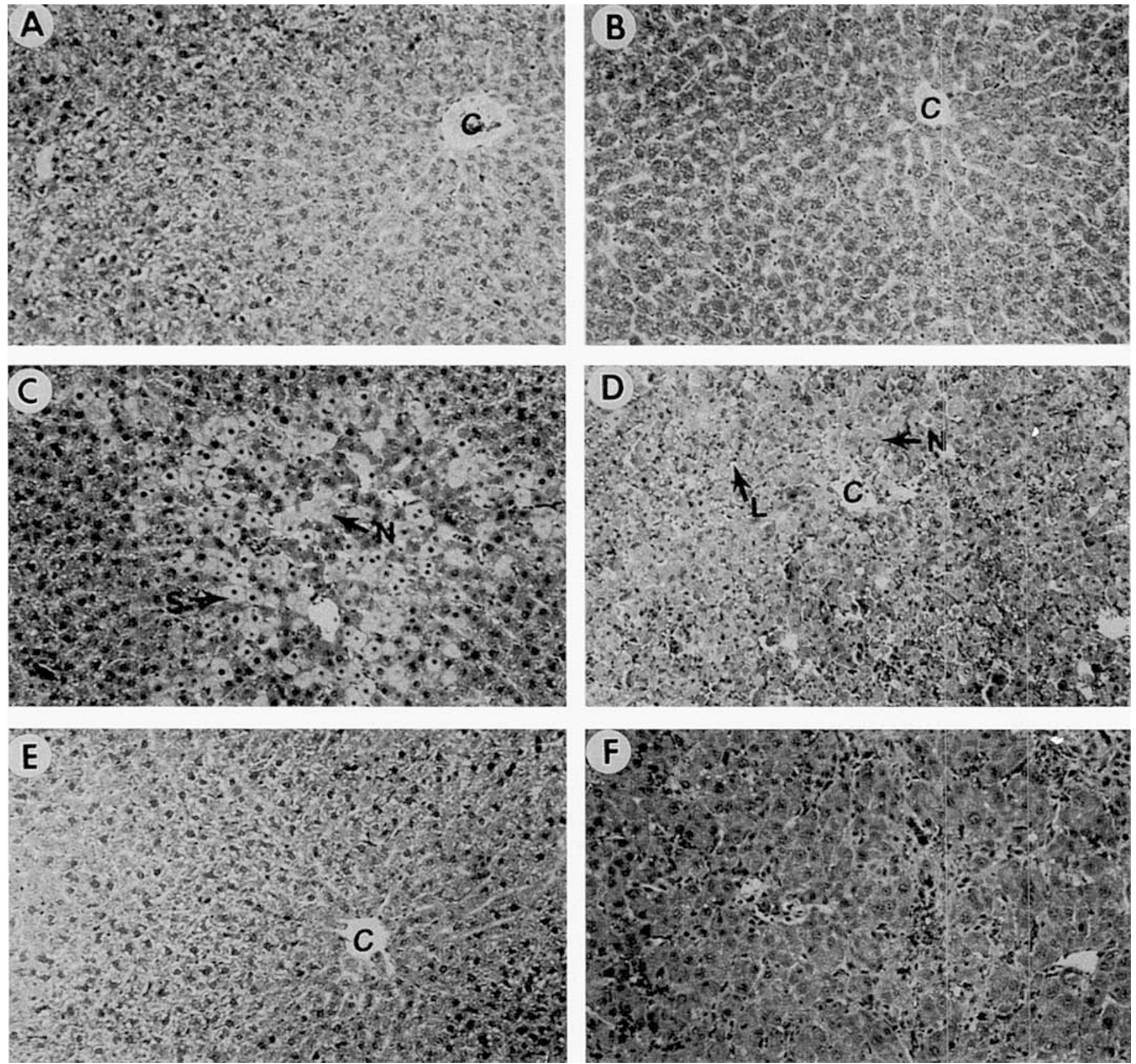

Figure 5. Photomicrographs of liver sections from 45 -d-old rats maintained on either ND or $10 \mathrm{ppm} \mathrm{CD}$ diet for $15 \mathrm{~d}$. On $\mathrm{d} 16$, they were challenged with a single nontoxic dose of $\mathrm{CCl}_{4}\left(100 \mu \mathrm{L} / \mathrm{kg}\right.$, i.p.). $A$, control for $\mathrm{ND} ; B$, control for $\mathrm{CD}$ diet; $C$, time of maximum injury (12 h) in ND $+\mathrm{CCl}_{4}$ group; $D$, time of maximum injury $(48 \mathrm{~h})$ in $\mathrm{CD}+\mathrm{CCl}_{4}$ group; $E$, time of recovery $(48 \mathrm{~h})$ in $\mathrm{ND}+\mathrm{CCl}_{4}$ group; $F$, time of recovery $(96 \mathrm{~h})$ in $\mathrm{CD}+\mathrm{CCl}_{4}$ group. Magnification, $\times 120 . C=$ central vein; $N=$ necrosis; $L=$ lipid; $S=$ swollen cells.

exposure to nontoxic level of $\mathrm{CD}$ in rats during postnatal development.

After a low dose of $\mathrm{CCl}_{4}(100 \mu \mathrm{L} / \mathrm{kg})$, transient liver injury occurs regardless of age between 6 and $36 \mathrm{~h}$ as evidenced by elevation of serum ALT, SDH, total bilirubin (Figs. 1-3), and histopathologic observations (Figs. 4-6; $A, C$, and $E$ ). During this period of injury, ongoing (20 and $45 \mathrm{~d}$ ) as well as stimulated hepatocellular regeneration were evident until $48 \mathrm{~h}$ as evidenced by $\left[{ }^{3} \mathrm{H}\right] \mathrm{T}$ incorporation data (Fig. 7). This response was much stronger in 20 -d rats compared with that in 45- and 60-d rats. Consequently, progression of tissue injury in 20-d-old rats was restrained much more effectively. In CD- treated rats, $\mathrm{CCl}_{4}$-induced hepatotoxicity led to 25 and $100 \%$ mortality in 45 - and 60 -d-old rats, respectively. The role played by the quiescent nature of adult liver cells in restraining the progression of injury is amply evident here. Hepatocellular regenerative activity was not evident in 60-d rats until $48 \mathrm{~h}$. This was too little and too late to restrain the progression of liver injury, consequently leading to liver failure and mortality in 60 -d-old rats. In contrast to the quiescence of adult liver, remarkable plasticity of the growing livers enables the younger rats to restrain the progression of injury in an inverse relationship to age. Despite experiencing similar liver injury, 20- and $45-d$ rats differ in that this injury becomes progressive in $45-d$ 

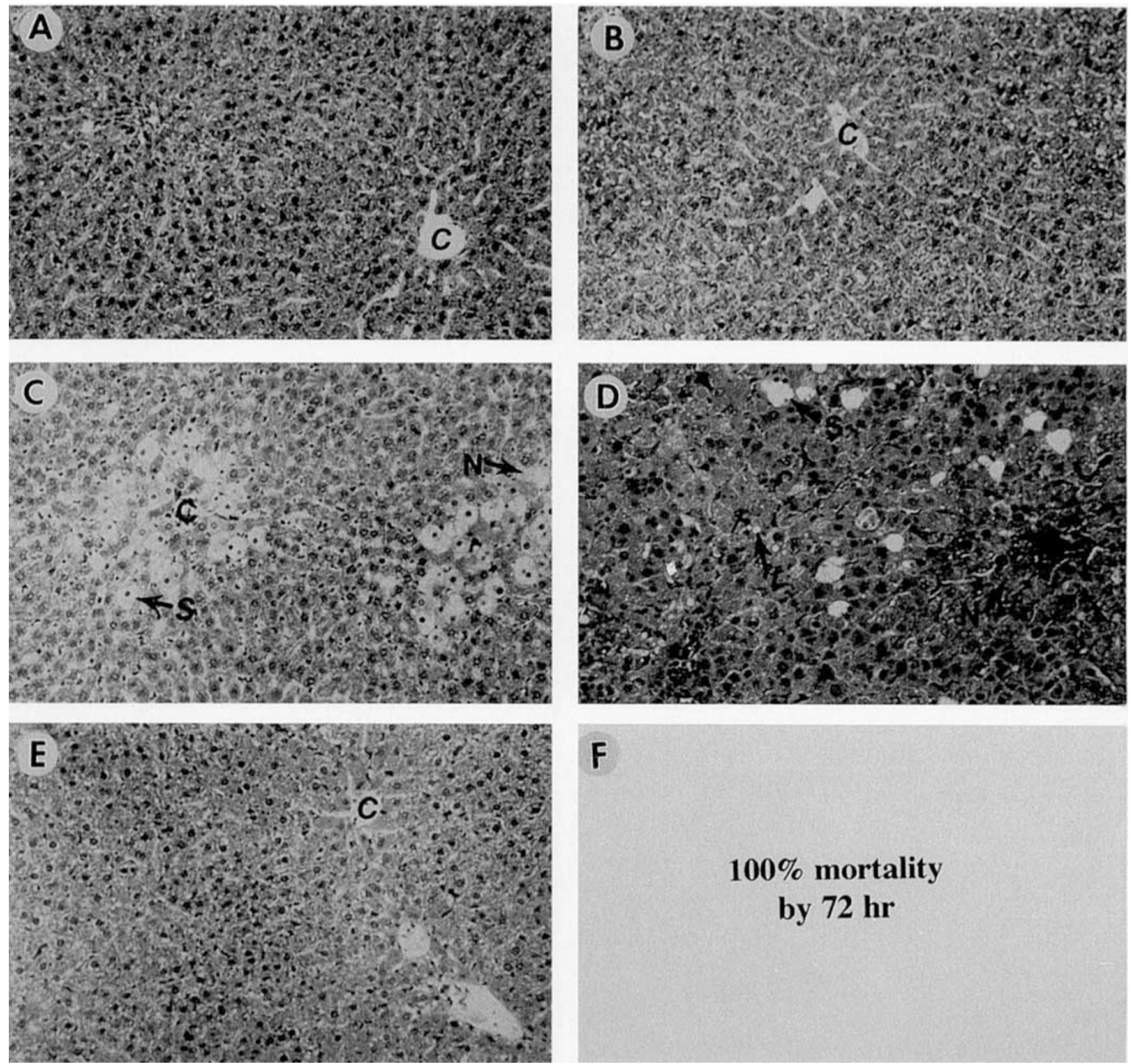

Figure 6. Photomicrographs of liver sections from 60 -d-old rats maintained on either ND or $10 \mathrm{ppm} \mathrm{CD}$ diet for $15 \mathrm{~d}$. On d 16, they were challenged with a single nontoxic dose of $\mathrm{CCl}_{4}\left(100 \mu \mathrm{L} / \mathrm{kg}\right.$, i.p.). $A$, control for $\mathrm{ND} ; B$, control for $\mathrm{CD}$ diet; $C$, time of maximum injury $(12 \mathrm{~h})$ in $\mathrm{ND}+\mathrm{CCl}{ }_{4}$ group; $D$, time of maximum injury $(48 \mathrm{~h})$ in $\mathrm{CD}+\mathrm{CCl}_{4}$ group; $E$, time of recovery $(24 \mathrm{~h})$ in $\mathrm{ND}+\mathrm{CCl}_{4}$ group; $F$, time at which $100 \%$ mortality occurred $(72 \mathrm{~h})$ in $\mathrm{CD}+\mathrm{CCl}{ }_{4}$ group. Magnification, $\times 120 . C=$ central vein; $N=$ necrosis; $L=$ lipid; $S=$ swollen cells.

rats, leading to $25 \%$ mortality, whereas 20 -d rats recover fully. In 45-d CD rats, hepatocellular regeneration and tissue repair increased significantly between 36 and $72 \mathrm{~h}$ after the administration of $\mathrm{CCl}_{4}$, as indicated by $\left[{ }^{3} \mathrm{H}\right] \mathrm{T}$ incorporation and mitotic index. In contrast to the effect in 45- and 60-d CDtreated rats, $\mathrm{CD}$ treatment did not affect ongoing liver growth or $\mathrm{CCl}_{4}$-stimulated hepatocellular regeneration and tissue repair in 20-d rats, which is in agreement with previous studies (5). In 20-d-old rats, regardless of diet, significant hepatocellular regeneration and tissue repair were evident at $24 \mathrm{~h}$, continuing throughout $72 \mathrm{~h}$ after the administration of $\mathrm{CCl}_{4}$, as indicated by increased $\left[{ }^{3} \mathrm{H}\right] \mathrm{T}$ incorporation and mitotic index.
These findings indicate that the remarkable plasticity of growing livers in younger rats enables them to recover from injury by additional prompt stimulation of hepatocellular regeneration and tissue repair.

The extent of $\mathrm{CCl}_{4}$-induced liver injury in all $\mathrm{CD}$ treated rats was comparable regardless of age. This is clearly evident from histopathological observations of liver sections. However, serum enzyme elevations (ALT, SDH) are not equal because younger rat livers contain roughly 3-fold less ALT and SDH (our unpublished observations). Therefore, in age-related studies serum enzyme elevations should be used with caution for quantitative estimations of liver injury. Ongoing liver growth 


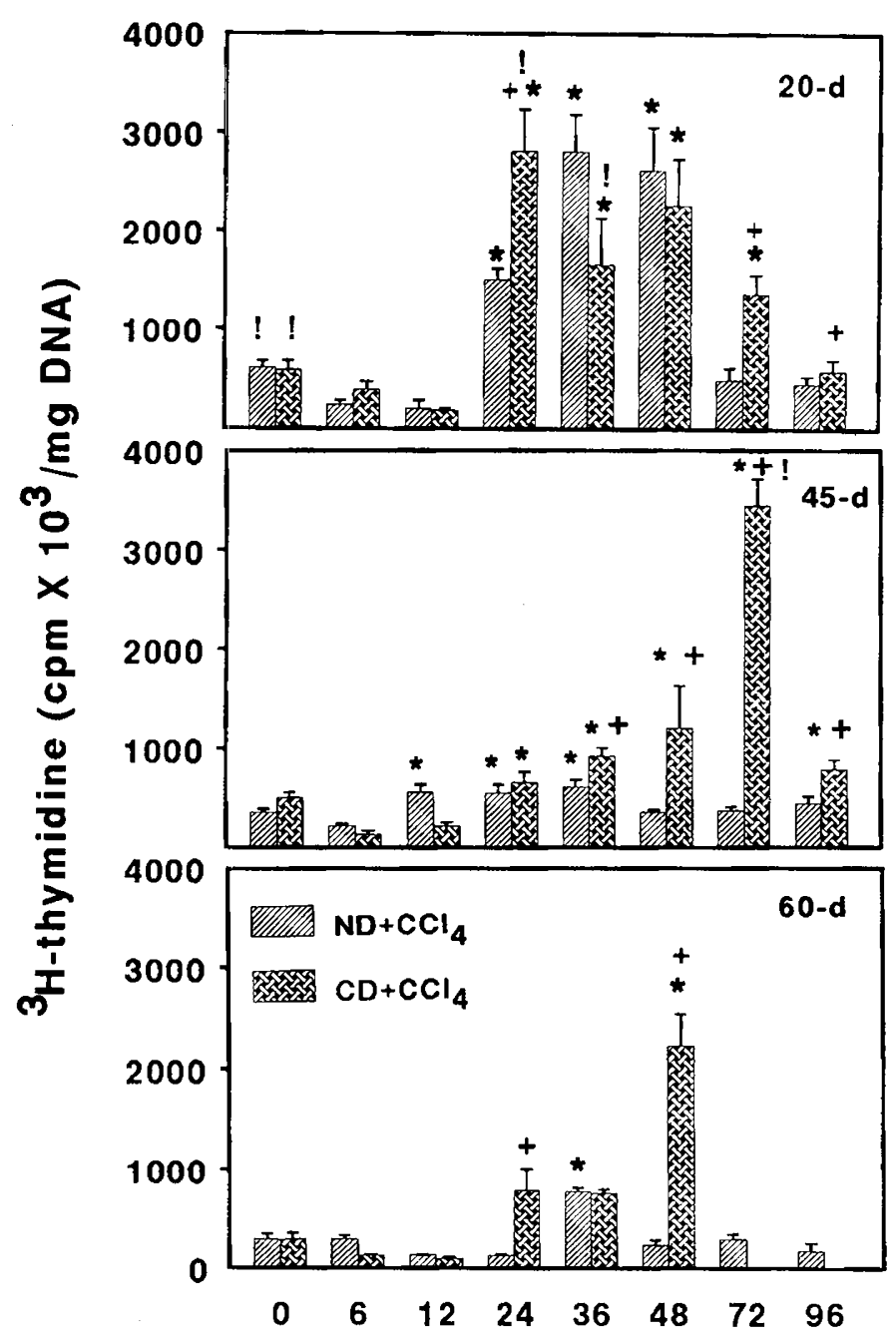

Hours after $\mathrm{CCl}_{4}$ administration

Figure 7. $\left[{ }^{3} \mathrm{H}\right]$ thymidine incorporation into hepatic nuclear DNA during a time course after $\mathrm{CCl}_{4}(100 \mu \mathrm{L} / \mathrm{kg}$, i.p. $)$ administration to 20 -, $45-$, and 60-d-old rats maintained on either ND or $10 \mathrm{ppm} \mathrm{CD} \mathrm{dict} \mathrm{for} 15 \mathrm{~d}$. Values are means \pm SEM of four rats. $*=$ Significantly higher as compared with the respective control group $(0 \mathrm{~h}$ time point $) ;+=$ significantly higher as compared with $\mathrm{ND}+\mathrm{CCl}_{4}$ rats at the corresponding time period; ! = significantly higher as compared with 60 -d-old $\mathrm{CD}+\mathrm{CCl}_{4}$ rats at the corresponding time.

and differences in the promptness of the hepatocellular regenerative response may be of pivotal importance in explaining the age-related differences in hepatotoxicity. Furthermore, agerelated differences in $\mathrm{CD}$-potentiated $\mathrm{CCl}_{4}$ hepatotoxicity and lethality are associated with the balance between two opposite biologic events occurring simultaneously. $\mathrm{CCl}_{4}$-induced liver injury (Fig. 8a) and tissue repair (Fig. $8 b$ ), as demonstrated by AUC for ALT and $\left[{ }^{3} \mathrm{H}\right] \mathrm{T}$ incorporation, respectively, illustrate this point. For example, the $\mathrm{AUC}$ for $\mathrm{CCl}_{4}$-induced liver injury in 20-d CD-treated rats is $1 / 10$ of that observed in $45-$ and 60-d rats. The AUC for tissue repair induced by $\mathrm{CCl}_{4}$ in 20 -d $\mathrm{CD}$-rats is about 5-fold larger than that observed in $60-\mathrm{d}$ CD-rats. The AUC for tissue repair in 45-d rats is similar to that calculated for 20 -d rats, correlating with the $75 \%$ survival of 45-d CD rats receiving $\mathrm{CCl}_{4}$.

Why are rats so efficient in tissue repair during early postnatal development? One reason is much higher efficiency of
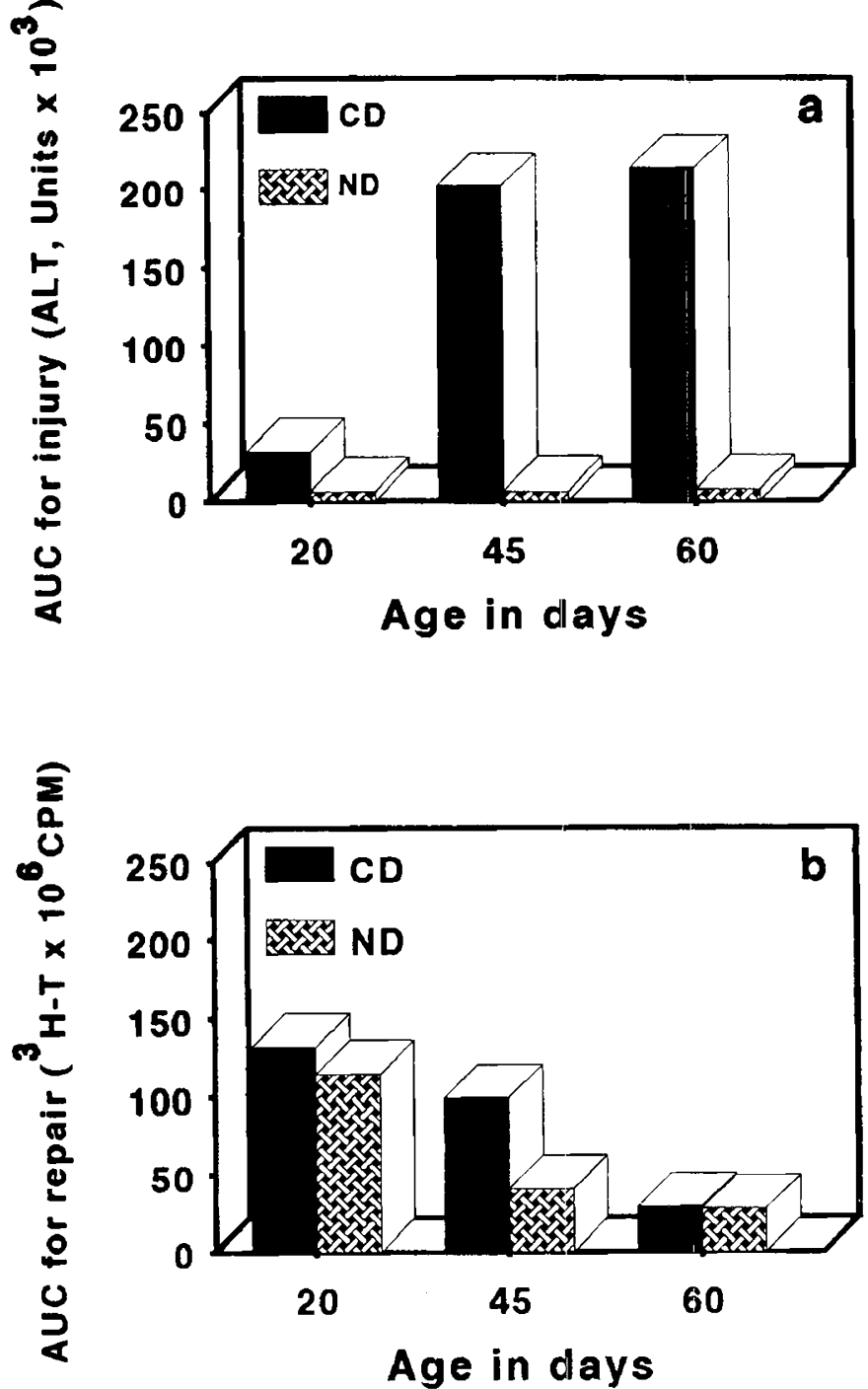

Figure 8. AUC for $\mathrm{CCl}_{4}$-induced tissue injury $(a)$ and tissue repair $(b)$ during a time course of $96 \mathrm{~h}$ after $\mathrm{CCl}_{4}(100 \mu \mathrm{L} / \mathrm{kg}$, i.p. $)$ administration to $20-, 45-$, and 60-d-old rats maintained on either ND or $10 \mathrm{ppm}$ CD diet for $15 \mathrm{~d}$.

DNA synthesis, as evidenced by the shorter duration required for $S$ phase and the cell cycle (28). In younger rats (21-d), both DNA synthesis and the ccll cycle require about half the time required for 56-d rats. Therefore, the quiescence of adult rat livers appears to be responsible for lesser and delayed tissue repair response, allowing in the interim the injury to progress in an unrestrained manner.

Studies indicate that hepatocellular regeneration is subject to regulation by growth factors such as TGF- $\alpha$ and TGF- $\beta$ (29, 30) whose expressions are developmentally regulated (31). TGF- $\alpha$ is known to be a powerful endogenous hepatocyte mitogen, whereas TGF- $\beta$ inhibits mitogenic stimulation induced by TGF- $\alpha(29,30)$. The expression of TGF- $\alpha$ increases upon tissue injury (32) and plays an important role in recovery (33). One other event that is thought to be essential for tissue regeneration is activation of specific proto-oncogenes which are known to influence the competency of surrounding cells to divide through "cell priming" $(29,34)$. Therefore, the possibility that the age-related differences observed in $\mathrm{CCl}_{4}$ hepa- 
totoxicity and its potentiation by $\mathrm{CD}$ is due to differences in the expressions of early proto-ocncogenes needs to be investigated. In addition to ongoing cell division, our findings also suggest that quicker and greater cell division response occurs during early postnatal development. This may either be due to quicker stimulation of TGF- $\alpha$ expression, or inhibition of TGF- $\beta$ expression, upon toxicant challenge.

In conclusion, the findings of the present study indicate that the resiliency of postnatally developing rats to the hepatotoxic and lethal effects of $\mathrm{CD}+\mathrm{CCl}_{4}$ combination is due to the hepatic plasticity in responding to injury by stimulated tissue repair. In contrast, the hepatocellular quiescence acquired with age leads to a slower and lower tissue repair response, leading to unrestrained progression of injury.

\section{REFERENCES}

1. Black M, Mitchell JR, Zimmerman HJ, Ishak KG, Epler GR 1975 Isoniazideassociated hepatitis in 114 patients. Gastroenterology 69:289-302

2. Rikans LE 1989 Influence of aging on chemically induced hepatotoxicity: Role of aging rclated changes in metabolism. Drug Metab Rev 20:87-110

3. Dawkins MJR 1963 Carbon tetrachloride poisoning in the liver of the newborn rats. J Pathol Bacteriol 85:189-196

4. Cagen SZ, Klaassen CD 1979 Hepatotoxicity of carbon tetrachloride in developing rats. Toxicol Appl Pharmacol 50:347-354

5. Cai Z, Mehendale HM 1993 Resiliency to amplification of carbon tetrachloride hepatotoxicity by chlordecone during postnatal devclopment in rats. Pediatr Res $33: 225-232$

6. Abdul-Hussain SK, Mehendale HM 1992 Ongoing hepatocellular regeneration and resilicncy in toward galactosamine hepatotoxicity. Arch Toxicol 66:729-742

7. Green MD, Shires TK, Fischer LJ 1984 Hepatotoxicity of acetaminophen in nconatal and young rats. I. Age-related changes in susceptibility. Toxicol Appl Pharmacol $74: 116-124$

8. Klingensmith JS, Mchendale $\mathrm{HM} 1982$ Potentiation of $\mathrm{CCl}_{4}$ lethality by chlordecone. Toxicol Lett 11:149-154

9. Agarwal AK, Mehendale HM 1983 Potentiation of $\mathrm{CCl}_{4}$ hepatotoxicity and lethality by chlordecone in female rats. Toxicology $26: 231-242$

10. Cheeseman KH, Albano EF, Tomasi A, Slater TF 1985 Biochemical studies on the metabolic action of halogenated alkanes. Environ Health Perspect 64:85-101

11. Kodavanti PRS, Kodavanti UP, Faroon OM, Mehendale HM 1992 Pivotal role of hepatocellular regeneration in the ultimate hepatotoxicity of $\mathrm{CCl}_{4}$ in chlordecone-, mirex-, or phenobarbital-pretreated rats. Toxicol Pathol 20:556-569

12. Mehendale HM 1990 Potentiation of halomethane toxicity by chlordeconc: A hy pothesis for the mechanism. Med Hypotheses 33:289-299

13. Kodavanti PRS, Joshi UM, Young RA, Bell AN, Mchendale HM 1989 Role of hepatocellular regeneration in chlordecone potentiated hepatotoxicity of carbon tetrachloride. Arch Toxicol 63:367-375
14. Curtis RL, Mchendale HM 1980 Specificity of chlordecone-induced potentiation of carbon tetrachloride hepatotoxicity. Drug Metab Dispos 8:23-27

15. Hewitt WR, Miyajima H, Cote MG, and Plaa GL 1980 Modification of haloalkaneinduced hepatotoxicity by exogenous ketones and metabolic ketosis. Fed Proc 39:31:18-3123

16. Lockard VG, O'Neal RM, Mehendale HM 1983 Chlordecone induced potentiation of carbon tetrachloride hepatotoxicity: A light and electron microscopic study. Exp Mol Pathol 39:230-245

17. Lockard VG, O'Neal RM, Mchendale HM 1983 Chlordecone induced potentiation of carbon tetrachloride hepatotoxicity: A morphometric and biochemical studies. Exp Mol Pathol 39:246-255

18. MacLeod SM, Renton KW, Eade NR 1972 Development of hepatic drug-oxidizing enzymes in immature male and female rats. J Pharmacol Exp Ther 183:489-498

19. Klaassen CD 1973 Hepatic excretory function in the newborn rat. J Pharmacol Exp Ther 184:721-728

20. Frank H, Haussman HJ, Remmer H 1982 Metabolic activation of carbon tetrachloride: Induction of cytochrome P-450 with phenobarbital or 3-methylcholanthrene and its effects on covalent binding. Chem Biol lnteract 40:193-208

21. Bergmeyer HU, Scheibe P, Waklefeld AW 1978 Optimization of methods for aspartate aminotransferase and alanine aminotransferase. Clin Chem 24:58

22. Asada M, Galambos JT 1963 Sorbitol dehydrogenase and hepatocellular injury: An experimental and clinical study. Gastroenterology 44:578-587

23. Michaelsson M 1961 Bilirubin determination in serum and urine. Studies on diazo methods and new copper-920 pigment method. Scand J Clin Lab Invest 13(suppl 56): $1-80$

24. Chang LO, Looney WB 1965 A biochemical and autoradiographic study of the in vivo utilization of tritiated thymidine in regenerating rat liver. Cancer Res 25:1817-1822

25. Burton K 1956 A study of the conditions and mcchanisms of the diphenylamine reaction for the colorimetric conditions of DNA. Biochem J 62:315-323

26. Kodavanti PRS, Joshi U M, Young RA, Meydrech EF, Mehendale HM 1989 Protection of hepatotoxic and lethal effects of $\mathrm{CCl}_{4}$ by partial hepatectomy. Toxicol Pathol 17:494-505

27. Rao VC, Mehendale HM 1991 Colchicine antimitosis abolishes $\mathrm{CCl}_{4}$ autoprotection. Toxicol Pathol 19:597-606

28. Altman PL, Dittmer DS (eds) 1972 Tissue growth and renewal: Mammals. In: Biology Data Book, 2nd Ed, Vol I. FASEB, Bethesda, MD, pp 95-115

29. Mead JE, Fausto N 1989 Transforming growth factor $\alpha$ may be a physiological regulator of liver regeneration by means of autocrine mechanism. Proc Natl Acad Sci USA $86: 1.558-1562$

30. Michalopoulos GK 1990 Liver regeneration: Molecular mechanism of growth control. FASEB J 4:176-187

31. Brown PI, Lam R, Lakshmanan J, Fisher DA 1990 Transforming growth factor- $\alpha$ in developing rats. Am J Physiol 259:E256-E260

32. Polk WH, Dempsey PJ, Russell WE, Brown PI, Beauchamp RD, Barnard JA, Coffey RJ 1992 Increased production of transforming growth factor $\alpha$ following acute gastric injury. Gastroenterology 102:1467-1474

33. Romano M, Polk WH, Awad JA, Arteaga CL, Nanney LB, Wargovich MJ, Kraus ER, Boland CR, Coffey RJ 1992 Transforming growth factor $\alpha$ protection against drug-induced injury to the rat gastric mucosa in vivo. J Clin Invest 90:2409-2421

34. Rollins BJ, Stiles CD 1988 Regulation of c-myc and c-fos proto-oncogene expression by animal cell growth factors. In Vitro Cell Dev Biol 24:81-84 